\title{
Preservice Teachers' Critical Thinking Dispositions and Web 2.0 Competencies
}

\author{
Serkan Sendag \\ Akdeniz University, Turkey \\ Osman Erol \\ Mehmet Akif University, Turkey \\ Sezan Sezgin \\ Mehmet Akif University, Turkey \\ Nihal Dulkadir \\ Anadolu University, Turkey
}

\begin{abstract}
The aim of this study was to investigate the associations between preservice teachers' Web 2.0 competencies and their critical thinking disposition (CTD). The study employed an associational research design using California Critical Thinking Disposition-Inventory (CCTD -I) and a Web 2.0 competency questionnaire including items related to Web 2.0 awareness, Web 2.0 use, and educational use of Web 2.0 tools. Five different Web 2.0 tools included in the study: (a) blogs, (b) wikis, (c) social networking websites, (d) YouTube, (e) podcasts. A total of 1335 preservice teachers completed the survey. Findings indicated that participants had a medium level internet use, Web 2.0 awareness, Web 2.0 use and Web 2.0 skills while their educational Web 2.0 use level was low. In terms of competencies on certain Web 2.0 tools, their blog, wiki and podcast competencies were at a very low level, whereas their social networking and YouTube competency levels were high. Findings also showed that there were significant relationships between preservice teachers' Web 2.0 competencies and their critical thinking disposition. The results highlighted that the use of different Web 2.0 tools can be complementary to each other during certain instructional activities to improve different dimensions of critical thinking disposition.
\end{abstract}

Keywords: Critical thinking; Higher order cognitive skills; Teaching-learning strategies; Web 2.0 awareness; Web 2.0 competencies; Preservice teacher education

\section{Introduction}

Recently, the role of future teachers seems more crucial than ever before for educational systems in terms of improvement of Critical Thinking (CT). In this context, promoting and modeling higher order thinking, and CT are recognized as a key standard for teachers by some of the institutions establishing standards for teacher preparation such as ISTE's NETS-T (International Society for 
Technology in Education, National Education Technology Standards for Teachers), NCATE (The Standard of Excellence in Teacher Preparation). Teacher preparation programs should be addressed to improve preservice teachers' CT skills and critical thinking disposition (CTD). Moreover, teacher educators should seek ways to facilitate disposition toward CT since the employment of CT skills are highly related to the inclination of CT. Therefore, in this study, we examine whether there are significant associations between preservice teachers' Web 2.0 competencies and CTD.

\section{Critical Thinking and Critical Thinking Disposition}

"Critical thinking" is a concept which dates back to Socrates' scholarly activities (Thayer-Bacon, 1998). Ever since then, critical thinking has been discussed because of the complex nature of the thinking process as well as the interest in thinking itself. Major disagreement on the issue has been whether CT is ability or disposition. In fact, CT can be considered a combination of abilities and dispositions (Ennis, 1987; Halpern, 1998). Ennis (1993) describes CT as, "reasonable reflective thinking that is focused on deciding what to believe or do" (p. 180). Paul (1988) defines CT as drawing conclusions from observations and knowledge. Consequently, CT requires an awareness of one's own thinking and reflection on the thinking of one's own self and others (Kuhn \& Dean, 2004). Therefore, taking responsibility for learning is a major component of CT, and can make individuals ready for understanding and acquisition of knowledge (Garrison, 1992; Garside, 1996). Individuals accumulate many standards and criteria to analyze and evaluate what they think, and this process steadily improves their ability (Paul \& Elder, 2001) to think critically. As a result, CT as a combination of abilities and dispositions can be defined as a knowledge and observation based thinking process that leads to decision-making.

CT consists of three major components: (a) disposition to CT, (b) prior learning experiences, and (c) CT skills. Firstly, CTD is an attitude toward CT, and a sense of responsibility for CT (Norris, 1989). Secondly, as Willingham (2008) argued, having adequate knowledge is essential for individuals to think critically, and prior learning experiences refer to gained knowledge through the activities. Hence, prior learning experiences are crucial in the process of problem solving, decision-making and evaluation in CT. Finally, CT skills refer to abilities that constitute CT.

Research shows that even though people have CT skills, individuals without thinking dispositions are defective in using their thinking abilities. The main idea behind this claim is that people may not think critically without CTD (Perkins, Farady, \& Bushey, 1991; Tishman, Jay, \& Perkins, 1993). The concept of CTD has been well-discussed as well as CT itself. CTD is considered more comprehensive than CT skills. CTD is necessary as a first step for presenting the CT skills. CTD has a potential of affecting one's capacity of CT. As a result, people need to have disposition toward CT in order to present CT skills. According to Facione (1990), CTD is a mental habit and some sort of intellectual virtue for CT. Facione, Facione, and Sanchez (1994) described seven features of CTD, "inquisitiveness, open-mindedness, systematicity, and analyticity, maturity, self-confidence, and truth seeking" (p.346). Ennis (2011) revealed several features of CTD: caring about the actuality of ones' own thoughts, searching for problems, taking into account others' views and reasons, seeking and offering reasons, and caring about others. 


\section{CTD in Preservice Teacher Education}

The literature provided a limited number of studies on CT in preservice teachers' preparation (Han \& Brown, 2013; Genc, 2008; McBride, Xiang, \& Wittenburg, 2002; Sendag \& Odabasi, 2009). There were two major lines of study on CT. The first one included studies that investigate the extent of preservice teachers CT level, and the relationships between some variables (e.g., academic level, gender, major) (Genc, 2008; Kezer, \& Turker, 2012; Myers \& Dyer, 2006). Some of the studies found associations between age, academic level, major, and CT (Genc, 2008; McBride et al., 2002; Turan, Kolayis, \& Ulusoy, 2012). According to some research, preservice teachers' CTD level was low, and also was higher than their CT skills (Zhou, Yan, Zhao, Liu, \& Xing, 2012; Yenice, 2011), and a significant relationship was found between CTD and CT skills (Profetto-McGrath, 2003). Some significant differences were also found related to subscales of CTD or CT skills (Genc, 2008; McBride et al., 2002). The second major group of studies on CT is the research investigating the improvement of CT among preservice teachers. One of the most important topics about CT is whether CT can be taught in formal educational settings. Moreover, what is the best way to teach $\mathrm{CT}$ ? Or, how could CT be acquired by learners through specific instructional activities?

Two major approaches have been discussed in the literature for the acquisition of CT: (a) subjectbased approach, and a (b) skill-based approach or process approach. According to some researchers, CT can be best learned by integrating CT activities into the whole curriculum (Hager \& Kaye, 1992; McPeck, 1991). This has been called a subject-based approach. In this approach, CT related issues such as CT skills, standards, and disposition toward CT are taught within the context of certain subject matters. Therefore, the instructional design and the implementation of subject matter can support improvement of CT. Moreover, all areas in a certain curriculum should be designed in a way that learners have an opportunity of employing their CT and transferring CT to all areas of their real lives. The instructional activities in a course should be associated with CTD and CT skills for effective results (Ennis, 1991). These instructional activities may also increase the learners' interest and motivation for the course materials and learning. On the other hand, the idea behind the skill-based approach refers to explicit CT courses. That is, CT can be acquired by its own content and curriculum (Ennis, 1987; Lipman 1991; Meyers, 1986).

Ennis (1987) argued that there are three types of learning and teaching CT: (a) general approach, (b) infusion and immersion approach, and (c) hybrid approach. The general approach, whose primary objective is to acquire CT skills, requires teaching CT in separate courses. The course content should include abstract conceptualization and philosophical beliefs. Ennis (1987) also stated that CT courses should be offered as a separate course in primary school, as specific CT courses in secondary education, and as informal logic courses in the university. Additionally, both preservice and in-service teachers should be involved in CT courses. In contrast, according to an infusion and immersion approach, CT can be best learned by integrating CT skills and disposition into subject matters. Teachers should be able to determine goals and objectives for both CT and subject matter. They need to teach the ability of establishing thematic links between cognitive and thinking skills, and transforming CT to other areas (Chambers, 1988). The hybrid approach is a combination of general approach and an infusion and immersion approach. In this approach, CT should be taught in explicit CT courses, but learners need to engage in activities or learning processes related to certain subject matters (Ennis, 1987). In this regard, all these approaches 
implicate how preservice teacher education has a crucial role in the process of teaching, integrating, and modeling CT.

The literature on the improvement of preservice teachers' CT highlights the following points: (a) constructivist methods such as problem-based learning, and inquiry-based learning have a positive effect on improving preservice teachers' CT (Cherubini, 2009; Sendag \& Odabasi, 2009), (b) courses explicitly teaching CT improves preservice teachers' CT (Kong \& Seng, 2004), and (c) courses integrating $\mathrm{CT}$ related skills into their curriculum can improve CT skills and dispositions (Han \& Brown, 2013; Sezer, 2008).

\section{Web 2.0 Tools and Educational Use of Web 2.0}

The second generation Web applications, which are also known as Web 2.0 tools such as blogs, wikis, podcasts, and online social networks, provide educational inspiration for learning because of the main idea behind these tools: "sharing," "interaction," and "collaboration." There have been many Web 2.0 tools on the internet. However, we include five main tools: blogs, wikis, podcasts, online social networks, and YouTube within the scope the study. Hereafter, Web 2.0 tools refer to these five tools, and Web 2.0 competency includes Web 2.0 awareness, use, skill, and educational use of Web 2.0

Web 2.0 tools can provide interaction among instructors, learners, and content. As a result of these interactions, there has also been an opportunity to get feedback about learning outcomes for relevant stakeholders in social constructivist learning environments utilized by Web 2.0 tools (Ferdig, 2007; Harrison \& Thomas, 2009).

In the literature, providing reinforcement, feedback, collaboration, individualist learning, and highlevel interaction are considered among the advantages of Web 2.0 tools. The following highlights the educational benefits of Web 2.0 tools: (a) experiencing the process of revising, developing, and constructing new knowledge via learning communities, criticizing the ideas during the knowledge construction process, and providing feedback; (b) creating formal and informal learning communities out of the classroom, enabling time and distance-free discussions; (c) accessing information through different resources, and providing learners with time to confirm the new information; (d) providing an asset of ease of use for personal interests; and (e) opportunity to share professional experiences as well as observing, comparing and assessing different point of views (Ferdig, 2007; Grosseck, 2009; Harris \& Rea, 2009; Harrison \& Thomas, 2009; Jakes, 2007).

\section{Web 2.0 use in Preservice Teachers' Education}

Studies on Web 2.0 tools in preservice teachers' education show some evidence of employment of CT. Research on Web 2.0 tools in preservice teachers' education mostly focuses on blogs, wikis and online social networks because of the eligibility of these tools for instructional use. Use of blogs in preservice teachers' education is mostly based on the reflection and discussion of individual learning outcomes (Parkes \& Kajder, 2010). Wikis promote collaborative works (Wheeler, 2009), while online social networks are attractive because of their similarity to real life 
(Hinduja \& Patchin, 2008). Briefly, the literature review on instructional use of blogs, wikis, and online social networking in preservice teachers' education highlights the following points: (a) Communication and higher-order thinking: Using blogs in preservice teachers' education can promote reflective thinking, critical commenting, discussion, communication, and interaction between peers and instructors (Parkes \& Kajder, 2010; Wopereis, Sloep, \& Poortman, 2010; Yang, 2009). The use of wikis may help preservice teachers discuss the results of group work, improve teamwork spirit (Richardson, 2006; S. Wheeler, Yoemans, \& D. Wheeler, 2008), and enhance reflective thinking (Kop, 2007). Online social networking can also improve learner-learner, and learner-instructor interaction, and enhance communication and knowledge sharing (Ajjan \& Harsthone, 2008; Jones, Blackey, Fitzgibbon, \& Chew, 2010); (b) Learning support: Instructors can provide crucial support for preservice teachers' learning throughout blogging via sharing knowledge and experiences. Discussions and interactions in the course of blogging and online social networking process may help to understand critical concepts (Barnett, 2006; Yang, 2009). Learning support on blog use and how faculty can integrate blogging into their instruction can be useful for the efficient use of blogs for instruction (Loving, Schroeder, Kang, Shimek, \& Herbert, 2007). Using wikis may also help preservice teachers improve writing skills, organize information, and build new knowledge (Ma \& Yuen, 2008; S. Wheeler \& D. Wheeler, 2009). Wikis may also function as information repositories (Wheeler et al., 2008). Similarly, online social networking can be used to support classroom teaching and learning (Mason, 2006; Mazer, Murphy, \& Simonds, 2007). Moreover, use of faculty's online social networking during the instruction process can inspire ideas on how preservice teachers could use this technology in their profession (Wubbels, 2007); (c) Positive attitude: Preservice teachers usually have positive attitudes toward blogging (Ray \& Hocutt, 2006). Likewise, online social networking can enhance motivation in learning (Mazer et al, 2007); (d) Instructional methodology: Both blogs and wikis can be effectively integrated into constructivist teaching and learning environments in preservice teachers' education (Kapp \& Driscoll, 2010; Wheeler et al., 2008). Wikis and online social networks are more eligible for collaborative work, and creating learning communities, while blogs inspire selfdirection (Wenger, McDermott, \& Snyder, 2002; Wheeler, 2009).

Beyond providing learning support, enhancing positive attitudes toward Web 2.0, and accompanying certain instructional design methodologies, the literature review shows that the use of specific Web 2.0 tools has the potential to improve preservice teachers' CT (Kop, 2007; Wheeler et al., 2008; Yang, 2009). On the other hand, studying CTD within the context of Preservice teachers' Web 2.0 use seems neglected in the literature. Thus, the aim of this study is to examine whether there were associations between the preservice teachers' Web 2.0 competencies, and CTD level. The following research questions have been posed to accomplish the aims of the study:

1) What are the preservice teachers' (a) amount of Internet use, (b) competency levels of Web 2.0 use, and (c) levels of CTD?

2) Are there any significant differences in the level of preservice teachers' CTD scores related to their (a) amount of Internet use, (b) awareness about Web 2.0 tools, (c) use of Web 2.0, (d) skills of Web 2.0 use, and (e) use of Web 2.0 for educational purpose, and overall Web 2.0 competency? 
3) Are there any significant differences in the level of preservice teachers' CTD scores related to their competency of (a) blog, (b) wiki, (c) podcast, (d) online social network, and (e) YouTube use?

\section{Method}

\section{Design and Research Procedures}

Casual comparative research design, a very common type of associational research, was used in the study. In this type of research, correlations and relationships are investigated between dependent and independent variables. Casual comparative studies typically compare two or more group of subjects that involves at least one categorical variable (Fraenkel \& Wallen, 2011).Using a CTD scale and a survey on Web 2.0 competencies; we examined associations between CTD and different levels (categories) of Web 2.0 competencies.

\section{Participants}

The target population of the study was all the preservice teachers enrolled in a four-year teacher preparation program at a state university in Turkey. Of the nearly 2000 preservice teachers in the target population from the departments of Computer Education and Instructional Technologies $(\mathrm{N}=97)$, Turkish Language Teaching $(\mathrm{N}=168)$, Foreign Languages Education $(\mathrm{N}=146)$, Science Education ( $\mathrm{N}=116)$, Primary-school Mathematics Education ( $\mathrm{N}=148)$, Early Childhood Education $(\mathrm{N}=103)$, Elementary Teacher Education $(\mathrm{N}=107)$, Social Studies Education $(\mathrm{N}=158)$, Fine Arts Education ( $\mathrm{N}=106)$, Physical Education And Sport Department $(\mathrm{N}=69)$, and Guidance and Psychological Counselling ( $N=117), 1335$ responded to the questionnaire, which is $67 \%$ of the population representing all departments.

\section{Instrumentation}

California Critical Thinking Disposition-Inventory (CCTD-I) with a 20-item Web 2.0-tools competency questionnaire was used to collect data. Web 2.0-tools competency questionnaire was developed by the authors of the study in accordance with the relevant literature and five field expert opinions (see Appendix A). The questionnaire includes items about the participants' awareness, skills, frequency of Web 2.0 use, and frequency of educational use of Web 2.0. 5-point Likert-type rating system was used to get a score for each item.

The term "Web 2.0 tools" refers to five common Web 2.0 tools (blog, Wiki, podcast, social network and Youtube). "Web 2.0 awareness" refers to level of remembering or recognizing each Web 2.0 tool. "Web 2.0 use" refers to participants' recurrent use of each Web 2.0 tool in their daily lives. "Web 2.0 skills" refers to different ability levels for each Web 2.0 tool. "Educational use of Web 2.0" refers to employment of Web 2.0 use ability for educational purposes. Consequently, Web 2.0 competency is sum of "Web 2.0 awareness", "Web 2.0 use", "Web 2.0 skills", and "Educational use of Web.20". 
The CCTD-I was developed based on a Delphi study in 1990. The scale has seven subscales with 75 items with a Cronbach's alpha that ranged from .60 to .78 for the subscales, and for the overall scale the alpha was .90 .

The Turkish version of the scale was adopted by Kokdemir (2003) with a sample of 913 participants. The Turkish version has six subscales with 51 items. Cronbach's alpha for the subscales ranged from .61 to .78. According to the study, a total score of 240 or less referred to a low level of CTD, while a total score of 300 or more represented a high level of CTD. The subscales for the Turkish version are analyticity, self-confidence, inquisitiveness, open-mindedness, systematicity, and truth seeking (Kokdemir, 2003).

The Cronbach's alpha for the present study was also found as .849 for the overall scale, while the values ranged from .716 to .892 for subscales

\section{Findings}

\section{Web 2.0 Competency, CTD Level, Amount of Internet Use}

The amount of participants' Internet use were gathered by the multiplication of the two variables: "Average time spent for each Internet use (eight point likert-type scale from 1=less than 30 minutes... to $8=$ more than 10 hours)," and "the frequency of Internet use (six point likert-type scale from $1=$ once in a month... to $6=$ several times in a day)." The result was a three-level ordinal variable where $1=$ low, $2=$ medium, and $3=$ high.

Table 1. Amount of Internet Use

\begin{tabular}{|c|c|c|c|c|c|c|c|c|c|}
\hline & \multicolumn{2}{|c|}{$\begin{array}{l}1 \text { - Low } \\
(1.00-16.66)\end{array}$} & \multicolumn{2}{|c|}{$\begin{array}{l}2-\text { Medium } \\
(16.67-33.34)\end{array}$} & \multicolumn{2}{|c|}{$\begin{array}{l}3 \text { - High } \\
(33.35-48.00)\end{array}$} & \multirow[t]{2}{*}{ Mean } & \multirow[t]{2}{*}{ Median } & \multirow[t]{2}{*}{ Sd } \\
\hline & $\%$ & $\mathbf{N}$ & $\%$ & $\mathbf{N}$ & $\%$ & $\mathbf{N}$ & & & \\
\hline $\begin{array}{l}\text { Amount } \\
\text { of } \\
\text { Internet } \\
\text { Use }\end{array}$ & 40.9 & 546 & 33.4 & 446 & 25.6 & 342 & 11.28 & 2 & 6.866 \\
\hline
\end{tabular}

As shown in Table 1, 40.9\% of the participants had low levels of Internet use, $33.4 \%$ of the participants had medium levels of Internet use, and $25.6 \%$ of the participants had high levels of Internet use. Because the data showed non-normal distribution, the median value was used to identify the overall shape of the data. As a result, the participants had a medium level Internet use. 
Table 2. Web 2.0 Competencies

\begin{tabular}{|c|c|c|c|c|c|c|c|c|c|c|c|c|c|c|}
\hline & \multicolumn{2}{|c|}{1 - Very low } & \multicolumn{2}{|c|}{ 2-Low } & \multicolumn{2}{|c|}{$\begin{array}{c}3- \\
\text { Medium }\end{array}$} & \multicolumn{2}{|c|}{ 4-High } & \multicolumn{2}{|c|}{$\begin{array}{c}\text { 5-Very } \\
\text { High }\end{array}$} & \multirow[t]{2}{*}{ Mean } & \multirow[t]{2}{*}{ SD } & \multirow[t]{2}{*}{ Median } & \multirow[t]{2}{*}{ Level } \\
\hline & $\%$ & $\mathrm{n}$ & $\%$ & $\mathrm{n}$ & $\%$ & $\mathrm{n}$ & $\%$ & $\mathrm{n}$ & $\%$ & $\mathrm{n}$ & & & & \\
\hline $\begin{array}{l}\text { Web } 2.0 \\
\text { awareness }\end{array}$ & 8,6 & 115 & 16.5 & 220 & 49.6 & 662 & 17.2 & 229 & 8.0 & 107 & 2.871 & .814 & 3 & Medium \\
\hline Web 2.0 use & 14.8 & 197 & 31.3 & 417 & 43.8 & 584 & 8.8 & 117 & 1.4 & 19 & 2.498 & .719 & 3 & Medium \\
\hline $\begin{array}{l}\text { Web } 2.0 \\
\text { skills }\end{array}$ & 14.8 & 198 & 29.7 & 396 & 43.1 & 575 & 9.8 & 131 & 2.5 & 34 & 2.536 & .746 & 3 & Medium \\
\hline $\begin{array}{l}\text { Educational } \\
\text { Web } 2.0 \text { Use }\end{array}$ & 28.0 & 374 & 31.9 & 425 & 33.1 & 442 & 6.1 & 81 & .9 & 12 & 2.228 & .781 & 2 & Low \\
\hline $\begin{array}{l}\text { Blog } \\
\text { Competency }\end{array}$ & 58.4 & 779 & 18.4 & 245 & 12.3 & 164 & 7.0 & 93 & 4.0 & 53 & 1.890 & 1.031 & 1 & V. low \\
\hline $\begin{array}{l}\text { Wiki } \\
\text { Competency }\end{array}$ & 57.6 & 769 & 13.7 & 183 & 11.7 & 156 & 8.5 & 114 & 8.4 & 112 & 2.010 & 1.207 & 1 & V. low \\
\hline $\begin{array}{l}\text { Podcast } \\
\text { Competency }\end{array}$ & 86.8 & 1158 & 7.9 & 105 & 3.2 & 43 & 1.1 & 15 & 1.0 & 13 & 1.300 & .650 & 1 & V. low \\
\hline $\begin{array}{l}\text { Social } \\
\text { Network } \\
\text { Competency }\end{array}$ & 4.4 & 59 & 9.5 & 127 & 12.7 & 169 & 26.4 & 352 & 47.0 & 627 & 3.872 & 1.014 & 4 & High \\
\hline $\begin{array}{l}\text { YouTube } \\
\text { Competency }\end{array}$ & 10.6 & 142 & 9.0 & 120 & 15.9 & 212 & 28.0 & 373 & 36.5 & 487 & 3.590 & 1.151 & 4 & High \\
\hline $\begin{array}{l}\text { Web } 2.0 \\
\text { Competency }\end{array}$ & 13.7 & 183 & 37.3 & 498 & 40.0 & 533 & 8.2 & 109 & .8 & 11 & 2.533 & .654 & 2 & Low \\
\hline
\end{tabular}

In Table 2, frequencies and percentages for each variable level and their corresponding Mean, Standard Deviation, and Median values were provided to describe participants' overall Web 2.0 competency, Web 2.0 awareness, Web 2.0 use, Web 2.0 skills, and educational Web 2.0 use level. Since the data did not show normal distribution, median values were used for the overall assessments. Thus, participants' Web 2.0 awareness, Web 2.0 use, and Web 2.0 skills were at a medium level, while their level of educational Web 2.0 use was low. In terms of competencies on certain Web 2.0 tools, participants' blog, wiki, and podcast competencies were at a very low level, while their level of social networking and YouTube competency were high.

Table 3. CTD-I Level

\begin{tabular}{|c|c|c|c|c|c|c|c|c|c|c|}
\hline & \multicolumn{2}{|c|}{$\begin{array}{c}1-\text { Low } \\
(51-135)\end{array}$} & \multicolumn{2}{|c|}{$\begin{array}{r}2-\text { Medium } \\
(136-220)\end{array}$} & \multicolumn{2}{|c|}{$\begin{array}{c}3-\text { High } \\
(221-306)\end{array}$} & \multirow[t]{2}{*}{ Mean } & \multirow[t]{2}{*}{ SD } & \multirow[t]{2}{*}{ Median } & \multirow[t]{2}{*}{ Level } \\
\hline & $\%$ & $\mathrm{n}$ & $\%$ & $\mathbf{n}$ & $\%$ & $\mathbf{n}$ & & & & \\
\hline CTD-I & 0.5 & 7 & 63.4 & 846 & 36.1 & 481 & 211.40 & 24.742 & 2 & Medium \\
\hline
\end{tabular}

As shown in Table 3, we got three categories (1=Low level and represents scores between 51 and 135, $2=$ Medium level and represents the scores between 136 and 220, and 3= High level and 
represents the scores between 221 and 306). As a result, the data showed that participants' CTD was at a medium level.

The Amount of Internet Use and Web 2.0 Competency: Associations with CTD

Table 4. The Impact of Amount of Internet Use on CTD Scores

\begin{tabular}{llllllll}
\hline $\begin{array}{l}\text { The amount of } \\
\text { Internet use }\end{array}$ & $\mathbf{N}$ & $\begin{array}{l}\text { Mean } \\
\text { Rank }\end{array}$ & H & df & $\mathbf{p}$ & J-T & p \\
\hline Low & 546 & 658.51 & 2.061 & 2 & .357 & 291390 & .244 \\
\hline Medium & 446 & 658.73 & & & & & \\
\hline High & 342 & 693.29 & & & & & \\
\hline
\end{tabular}

As shown in Table 4, there were no significant differences in the level of the participants' CTD scores in relation to amount of Internet use $(H(2)=2.061 ; p>.05)$. In other words, there was no relationship between the amount of Internet use and participants' CTD level.

The $\mathrm{H}$ test was employed to explore if there were significant differences in the level of the participants' CTD scores in regards to their levels of (a) awareness about Web 2.0, (b) Web 2.0 use, (c) Web 2.0 skills, and (d) educational use of Web 2.0. Mann-Whitney $U$ test with a Bonferroni correction was run as a follow-up for multiple comparisons after a significant $H$ value. As we had three groups in each level of Web 2.0 competence, the adjusted critical value was $.016(.05 / 3)$.

Table 5. The Impact of Web 2.0 Competency on CTD Scores

\begin{tabular}{|c|c|c|c|c|c|c|c|c|c|c|}
\hline \multirow{2}{*}{$\begin{array}{c}\text { Levels of Web } \\
2.0 \\
\text { Competencies }\end{array}$} & \multirow[b]{2}{*}{$\mathbf{N}$} & \multirow[b]{2}{*}{ H } & \multirow[b]{2}{*}{ df } & \multirow[b]{2}{*}{$\mathbf{p}$} & \multirow[b]{2}{*}{ J-T } & \multirow[b]{2}{*}{$p$} & \multicolumn{3}{|c|}{ Mean Rank } & \multirow{2}{*}{$\begin{array}{l}\text { Between Group } \\
\text { Differences * }\end{array}$} \\
\hline & & & & & & & 1-Low & $\begin{array}{l}\text { 2- } \\
\text { Medium }\end{array}$ & 3-High & \\
\hline Awareness & 1334 & 7.39 & 2 & .025 & 294506.5 & .006 & 634.42 & 672.74 & 702.31 & $(1-3)$ \\
\hline Use & 1334 & 8.75 & 2 & .013 & 295731.5 & .005 & 639.43 & 653.47 & 710.86 & $(2-3),(1-3)$ \\
\hline Skills & 1334 & 11.09 & 2 & .004 & 294445.5 & .001 & 624.64 & 672.08 & 706.94 & $(1-3)$ \\
\hline $\begin{array}{l}\text { Educational Web } \\
2.0 \text { use }\end{array}$ & 1334 & 9.65 & 2 & .008 & 294940 & .002 & 630.85 & 670.77 & 711.17 & $(1-3)$ \\
\hline $\begin{array}{l}\text { Overall Web } 2.0 \\
\text { competency }\end{array}$ & 1334 & 13.577 & 2 & .001 & 296420.5 & .000 & 627.63 & 656.30 & 720.05 & $(2-3),(1-3)$ \\
\hline
\end{tabular}

As shown in Table 5, data indicated that there were significant differences between the participants' levels of Web 2.0 awareness $(H(2)=7.390, p<.05)$, Web 2.0 use $(H(2)=8.753, p<.05)$, Web 2.0 skills $(H(2)=11.085, p<.05)$, and educational Web 2.0 use $(H(2)=9.651, p<.05)$ related to their CTD level. More specifically, participants with high level Web 2.0 awareness had higher CTD as compared to those participants with low level awareness. In addition, a J-T test revealed that the more the participants have awareness about Web 2.0, the more they tend to think critically ( $\mathrm{J}$ $T=294506.5, p<.05)$. Similarly, participants with high level Web 2.0 skills had higher CTD than the participants with low level Web 2.0 skills, and the J-T test indicated that the more the participants have Web 2.0 skills, the more they tend to think critically $(J-T=294445.5, p<.05)$. Participants with high level Web 2.0 use had higher CTD as compared to those participants with medium or low 
level Web 2.0 use, and the J-T test showed that the more the participants use Web 2.0, the more they tend to think critically $(J-T=295731.5, p<.05)$. Participants with high level educational Web 2.0 use had higher CTD as compared to those participants with low level educational Web 2.0 use. The more the participants use Web 2.0 for educational purposes, the more they tend to think critically $(J-T=294940, p<.05)$. In addition, there was a significant relationship between overall Web 2.0 competency level and participants' CTD level $(H(2)=13.577, p<.05)$. Participants with high level overall Web 2.0 competency had higher CTD as compared to those participants with low and medium level Web 2.0 competency. The more the participants use Web 2.0 competently, the more they tend to think critically.

The Competencies about Blog, Wiki, Podcast, Social Network, and YouTube: Associations with CTD

As shown in Table 6, the data analyses showed that there were significant differences in the level of participants' CTD scores in relation to their competency level of using blogs $(H(2)=12.195, p<$ $.05)$, social networks $(H(2)=16.835, p<.05)$, and YouTube $(H(2)=10.571, p<.05)$, while no significant relationship was found between wiki competency and CTD. Participants with high level blog competency had higher CTD as compared to both participants with medium and low level blog competency. Participants with high level online social network competency had higher CTD than the participants with low level competency, and the participants with medium level online social network competency had higher CTD than the participants with low level online social network competency. The participants with high level YouTube competency had higher CT as compared to those participants with low level YouTube competency. J-T test indicated that the more competently the participants used blogs, online social networks, and YouTube, the more they tended to think critically. Because we did not have an eligible number of participants in the high level podcast group for the $\mathrm{H}$ test analysis, we ran Mann-Whitney $\mathrm{U}$ test for the low and medium groups. The participants' podcast competency showed no significant relationship with CTD.

Table 6. Results of H Test on the Impact of Competencies about Blog, Wiki, Podcast, Social Network, and YouTube on CTD

\begin{tabular}{|c|c|c|c|c|c|c|c|c|c|c|}
\hline \multirow[b]{2}{*}{ Competency of } & \multirow[b]{2}{*}{$\mathbf{N}$} & \multirow[b]{2}{*}{$\mathbf{H}$} & \multirow[b]{2}{*}{ df } & \multirow[b]{2}{*}{$\mathbf{p}$} & \multirow[b]{2}{*}{ J-T } & \multirow[b]{2}{*}{$\mathbf{P}$} & \multicolumn{3}{|c|}{ Mean Rank } & \multirow{2}{*}{$\begin{array}{l}\text { Between } \\
\text { Group } \\
\text { Differences * }\end{array}$} \\
\hline & & & & & & & 1-Low & $\begin{array}{l}\text { 2- } \\
\text { Medium }\end{array}$ & 3-High & \\
\hline Blog & 1334 & 12.195 & 2 & .002 & 295411.5 & .002 & 640.11 & 643.54 & 719.87 & $(2-3),(1-3)$ \\
\hline Wiki & 1334 & 2.476 & 2 & .290 & 292604 & .232 & 658.86 & 651.97 & 690.98 & -- \\
\hline Social Network & 1334 & 16.835 & 2 & .000 & 295008 & .000 & 607.77 & 681.01 & 708.90 & $(1-2),(1-3)$ \\
\hline YouTube & 1334 & 10.571 & 2 & .005 & 294645.5 & .001 & 623.27 & 677.84 & 702.64 & $(1-3)$ \\
\hline
\end{tabular}

\section{Discussion and Conclusions}

The study investigated the relationships between preservice teachers' Web 2.0 competencies and CTD. Findings indicated that participants had a medium level CTD. Similarly, earlier studies found low or medium level CT among preservice teachers (Zhou et al., 2012; Yenice, 2011). Considering 
the sample size (1335) of the study, this finding should be critical to Turkey's teacher preparation programs. Having the tendency of thinking critically for futures' teachers is very important as the future teachers will be the role model for their students. This is why contemporary teacher education standards recognize the importance of modeling higher order thinking (ISTE, 2008; NCATE, 2008). On the other hand, improving preservice teachers' CT throughout their education can be facilitated employing the technologies that require more learner intervention, engagement, and interaction. In other words, using any technology may not be efficient in improving preservice teachers' CT. In this context, the findings showed that the participants had a medium level internet use amount and CTD. In addition, there was no significant relationship between participants' internet use amount and CTD. It can be supported that the time spent on the Internet cannot be associated with preservice teachers' disposition toward CT. CTD requires higher order cognitive and emotional engagement such as truth seeking, systematicity, and analyticity. Thus, there can be both low and high level activities that might either encourage or discourage high level cognitive and affective presence on the internet. It can be concluded that such activities requiring learners' higher order mental and affective engagement should be facilitated with the efficient use of technology to promote CTD in Preservice teacher education. Employing Web 2.0 tools in preservice teachers' education may have a potential of improving learners' CT because these tools help promote discussion, communication, interaction, reflective thinking, critical commenting, (Barnett, 2006; Parkes \& Kajder, 2010; Wopereis et al., 2010; Yang, 2009). For example discussion, communication, and interaction can be associated with open mindedness to others' view, truth seeking, and maturity, which are subdomains of CTD according to Facione et al.(1994).

It is very important to understand the preservice teachers Web 2.0 use by data. In this regard, findings indicated that participants had high level YouTube and social networking competencies, and very low level blog, wiki, and podcast competencies. There may be several factors that support these results. Common use of YouTube and social networking among preservice teachers may have caused construction of such a perception. It seems that uses of blogs, wikis, and podcasts are not very common among preservice teachers in Turkey. However these tools are very important to stimulate preservice teachers' engagement, motivation, teamwork, interaction and higher order cognitive skills as suggested in earlier studies (Kop, 2007, Loving et al, 2007, Richardson, 2006; Wheeler et al, 2008). Therefore, the relationship between CTD and these tools were also investigated to discuss the role of Web 2.0 in CTD improvement of preservice teachers. More specifically, data indicated that participants with high levels of blog, YouTube, and social networking use had more dispositions toward CT as compared to those participants with particularly low levels of use. It can be concluded that employing certain Web 2.0 tools in instructional activities of teacher preparation programs may have a potential of contributing to the improvement of preservice teachers' disposition toward CT. However, experimental research studies would provide more insight to this end.

Findings also indicated that participants' wiki use showed no significant relationship with CTD. This result may seem to conflict with the results of current studies (Wheeler et al, 2008). Because the number of the participant that uses wikis very low further research focusing on this issue needs to be conducted to better understand the effect of wikis and appropriate methods/strategies on the improvement of preservice teachers' CT. Because the number of the participants in high and medlevel podcast user groups were not adequate for the associational analysis we could not report findings on preservice teachers' podcast use and CT. It appeared that the use of podcasts were less 
common among preservice teachers' in Turkey. However, the use of podcasts in teaching and learning to promote CTD can also be efficiently facilitated by getting the learners involved in the process of developing authentic podcasts. Further studies would contribute more to this point.

Within the scope of this study, Web 2.0 awareness refers to recognizing, remembering, and explain what a certain Web 2.0 tool is while use of Web 2.0 refers to the frequency of Web 2.0 use (repeated use of Web 2.0). Web 2.0 skills refer to the degree of feeling comfortable with a specific Web 2.0. Educational use of Web 2.0 refers to use of Web 2.0 in or outside the classroom for learning. Overall Web 2.0 competency is the combination of these different competencies. In this context, findings indicated that participants had a medium level Web 2.0 awareness, Web 2.0 use, and Web 2.0 skills, and low level educational Web 2.0 use, and overall Web 2.0 competency. It seems that preservice teachers had an average awareness, use, and skills about Web 2.0 while they do not use Web 2.0 for educational purposes. Use of Web 2.0 for educational purposes could have been perceived as using Web 2.0 in only the classroom or as part of classroom activities by the participants. Thus, this result also implies that the use of Web 2.0 in preservice teachers' education in Turkey is less common.

The earlier studies suggested that use of different Web 2.0 tools in the classroom can promote critical thinking (Richardson, 2006), and a few studies found the evidences that specific Web 2.0 tools can improve critical thinking (Mendenhall \& Johnson, 2010). In addition, findings of this study indicated that the participants with high levels of Web 2.0 awareness, Web 2.0 use, Web 2.0 skills, educational Web 2.0 use, and overall Web 2.0 competency significantly had more dispositions toward CT than those participants who had particularly low levels of these Web 2.0 competencies. It can be concluded that as well as preservice teachers' overall level of Web 2.0 competency, Web 2.0 awareness, use, skills, and educational use of Web 2.0 can be considered crucial variables that might have a potential effect on preservice teachers' tendency to $\mathrm{CT}$.

In the literature, there have been several studies suggesting the use of Web 2.0 in preservice teachers' education (Ferdig, 2007; Grosseck, 2009; Harris \& Rea, 2009; Harrison \& Thomas, 2009; Jakes, 2007) focusing on the use of a particular Web 2.0 tool (Mazer, et al., 2007; Wheeler et al., 2008; Wopereis et al., 2010). However, the current study found a significant positive relationship between overall Web 2.0 competency and CTD. These results coupled with the current literature may imply that the use of different Web 2.0 tools can be complementary to each other during certain instructional activities to improve different dimensions of CTD more effectively. In conclusion, in order to facilitate CTD effectively in preservice teachers' education, delivering a specific content with appropriate teaching and learning strategies that can match the nature of different Web 2.0 tools should be a concern of further research.

\section{References}

Ajjan, H. \& Hartshorne, R. (2008). Investigating faculty decisions to adopt Web 2.0 technologies: Theory and empirical tests. The Internet and Higher Education, 11(2), 71-80.

Barnett, M. (2006). Using a web-based professional development system to support preservice teachers in examining authentic classroom practice. Journal of Technology and Teacher Education, 14(4), 701-729. 
Chambers, J. H. (1988). Teaching thinking throughout the curriculum: Where else? Educational Leadership, 42(3), 4-6.

Cherubini, L. (2009). Exploring prospective teachers' critical thinking: Case-based pedagogy and the standards of professional practice. Teaching and Teacher Education, 25(2), 228-234. http://dx.doi.org/10.1016/j.tate.2008.10.007

Ennis, R. H. (1987). A taxonomy of critical thinking dispositions and abilities. In J. B. Barton \& R. J. Sternberg (Eds.), Teaching thinking skills: Theory and practice (9-26). New York: Freeman.

Ennis, R.H. (1991). Critical thinking: A streamlined conception. Teaching Philosophy, 14(1), 5-25.

Ennis, R. H. (1993). Critical thinking assessment. Theory into Practice, 32(3), 179-186. http://dx.doi.org/10.1080/00405849309543594

Ennis, R. H. (2011). The nature of critical thinking: An outline of critical thinking disposition and abilities. Retrieved on 27 January 2012 from http://faculty.education.illinois.edu/rhennis/ documents/TheNatureofCriticalThinking_51711_000.pdf

Facione, P. A. (1990). Critical thinking: A statement of expert consensus for purposes of educational assessment and instruction. Research findings and recommendations. ERIC Document Number: ED315423.

Facione, N. C., Facione, P. A., \& Sanchez, C. A. (1994). Critical thinking disposition as a measure of competent clinical judgment: the development of the California Critical Thinking Disposition Inventory. The Journal of Nursing Education, 33(8), 345-350.

Ferdig, R. (2007). Examining social software in teacher education. Journal of Technology and Teacher Education, 15(1), 5-10.

Field, A. (2005). Discovering statistics using SPSS (2th ed.). London: Sage.

Fraenkel, J.R. \& Wallen, N.E. (2011). How to design and evaluate research in education. New York: McGraw-Hill.

Garrison, D. R. (1992). Critical thinking and self-directed learning in adult education: An analysis of responsibility and control issues. Adult Education Quarterly, 42(3), 136-148.

Garside, C. (1996). Look who's talking: A comparison of lecture and group discussion teaching strategies in developing critical thinking skills. Communication Education, 45(3), 212-227. http://dx.doi.org/10.1080/03634529609379050

Genc, S. Z. (2008). Critical thinking tendencies among teacher candidates. Educational Sciences: Theory and Practice, 8(1), 107-116. Retrieved on 5 July 2013 from http://www.eric.ed.gov/ ERICWebPortal/detail?accno=EJ796251

Grosseck, G. (2009). To use or not to use web 2.0 in higher education? Procedia-Social and Behavioral Sciences, 1(1), 478-482

Hager, P. \& Kaye, M. (1992). Critical thinking in teacher education: A process-oriented research agenda. Australian Journal of Teacher Education, 17(2),4.

Halpern, D. F. (1998). Teaching critical thinking for transfer across domains: Disposition, skills, structure training, and metacognitive monitoring. American Psychologist, 53(4), 449. 
Han, H.S. \& Brown, E. T. (2013). Effects of critical thinking intervention for early childhood teacher candidates. The Teacher Educator, 48, 110-127.

Harris, A. L. \& Rea, A. (2009). Web 2.0 and virtual world technologies: A growing impact on IS education. Journal of Information Systems Education, 20(2), 137-144.

Harrison, R. \& Thomas, M. (2009). Identity in online communities: Social networking sites and language learning. International Journal of Emerging Technologies \& Society, 7(2), 109-124.

Hinduja, S. \& Patchin, J. W. (2008). Personal information of adolescents on the Internet: A quantitative content analysis of MySpace. Journal of Adolescence, 31, 125-146.

ISTE, (2008). International Society for Technology in Education, Standards-Teachers, http://www.iste.org/docs/pdfs/20-14_ISTE_Standards-T_PDF.pdf

Jakes, D. (2007). Web 2.0 and the new visual literacy. Technology and Learning, 27(9), 21.

Jones, N., Blackey, H., Fitzgibbon, K., \& Chew, E. (2010). Get out of MySpace!. Computers \& Education, 54(3), 776-782.

Kapp, K. M. \& O'Driscoll, T. (2010). Learning in 3D: Adding a new dimension to enterprise learning and collaboration. San Francisco, CA: Pfeiffer.

Kezer, F. \& Turker, B. (2012). Comparison of the critical thinking dispositions of (studying in the secondary science and mathematics division) preservice teachers. Procedia-Social and Behavioral Sciences, 46, 1279-1283. http://dx.doi.org/10.1016/j.sbspro.2012.05.288

Kong, S. \& Seng, S. (2004). Enhancing critical thinking skills and dispositions of pre-service teachers. The Korean Journal of Thinking and Problem Solving, 14(2), 41-56.

Kop, R. (2007). Blogs and Wikis as disruptive technologies: Is it time for a new pedagogy? In M. Osborne, M. Houston, \& N. Toman (Eds.), The Pedagogy of lifelong learning (192-202). London and New York: Routledge.

Kokdemir, D. (2003). Belirsizlik durumlarinda karar verme ve problem cozme [Decision making and problem solving under uncertainty] (Unpublished doctoral dissertation). Ankara University Institute of Social Sciences, Ankara.

Kuhn, D. \& Dean, D. (2004). A bridge between cognitive psychology and educational practice. Theory into Practice, 43(4), 268-273.

Lipman, M. (1991). Thinking in education. Cambridge: Cambridge University Press.

Loving, C. C., Schroeder, C., Kang, R., Shimek, C., \& Herbert, B. (2007). Blogs: Enhancing links in a professional learning community of science and mathematics teachers. Contemporary Issues in Technology and Teacher Education, 7(3), 178-198.

Ma, W.W.K., \& Yuen, A.H.K. (2008). News writing using wiki: impacts on learning experience student journalists. Educational Media International, 45(4), 295-309.

Mason, R. (2006). Learning technologies for adult continuing education. Studies in Continuing Education, 28(2), 121-133. 
Mazer, J. P., Murphy, R. E., \& Simonds, C. J. (2007). I'll see you on "Facebook": The effects of computer-mediated teacher self-disclosure on student motivation, affective learning, and classroom climate. Communication Education, 56(1), 1-17.

McBride, R., Xiang, P., \& Wittenburg, D. (2002). Dispositions Toward Critical Thinking: The Preservice Teacher's Perspective. Teachers and Teaching: Theory and Practice, 8(1), 29-40.

McPeck, J. E. (1991). What is learned in informal logic courses? Teaching Philosophy, 14(1), 25-34.

Mendenhall, A. \& Johnson, T. E. (2010). Fostering the development of critical thinking skills, and reading comprehension of undergraduates using a Web 2.0 tool coupled with a learning system. Interactive Learning Environments, 18(3), 263-276.

Meyers, C. (1986). Teaching students to think critically: A guide for faculty in all disciplines. San Fransisco: Jossey Bass.

Myers, B. E. \& Dyer, J. E. (2006). The influence of student learning style on critical thinking skill. Journal of Agricultural Education, 74(1), 43-52.

NCATE. (2008). The Standard of Excellence in Teacher Preparation, Unit Standards in Effect 2008 http://www.ncate.org/Standards/UnitStandards/UnitStandardsinEffect2008/tabid/ 476/Default.aspx

Norris, S. P. (1989). Can we test validly for critical thinking? Educational Researcher, 18(9), 21-26.

Parkes, K. A. \& Kajder, S. (2010). Eliciting and assessing reflective practice: A case study in Web 2.0 technologies. International Journal of Teaching and Learning in Higher Education, 22(2), 218-228.

Paul, R. (1988). Critical thinking in the classroom. Teaching $K, 8(18), 49-51$.

Paul, R. \& Elder, L. (2001). Critical thinking: Tools for talking charge of your learning and your life. Upper Saddle River, NJ: Prentice Hall.

Perkins, D. N., Farady, M., \& Bushey, B. (1991). Everyday reasoning and the roots of intelligence. In J. Voss, D. N. Perkins \& J. Segal (Eds.), Informal reasoning (pp. 83-105). Hillsdale, NJ: Erlbaum

Profetto-McGrath, J. (2003). The relationship of critical thinking skills and critical thinking dispositions of baccalaureate nursing students. Journal of Advanced Nursing, 43(6), 569-577.

Ray, B. B., \& Hocutt, M. M. (2006). Teacher-created, Teacher-centered weblogs: Perceptions and practices. Journal of Computing in Teacher Education, 23(1), 11-18.

Richardson, W. (2006). Blogs, wikis, podcasts and other powerful Web tools for classrooms. Thousand Oaks, CA: Corwin Press.

Sezer, R. (2008). Integration of critical thinking skills into elementary school teacher education courses in mathematics. Education, 128, 349-362.

Sendag, S. \& Odabasi, H. F. (2009). Effects of an online problem based learning course on content knowledge acquisition and critical thinking skills. Computers \& Education, 53(1), 132-142.

Thayer-Bacon, B. (1998). Transforming and redescribing critical thinking: Constructive thinking. Studies in Philosophy and Education, 17(2/3), 123-148. 
Tishman, S., Jay, E., \& Perkins, D. N. (1993). Teaching thinking dispositions: From transmission to enculturation. Theory into Practice, 32(3), 147-153.

Turan, H., Kolayis, H., \& Ulusoy, Y. O. (2012). Comparison of the faculty of education students' critical thinking disposition. Procedia-Social and Behavioral Sciences, 46, 2020-2024.

Wenger, E., McDermott, R., \& Snyder, W. M. (2002). Cultivating communities of practice. London, UK: HBS Press.

Wheeler, S. (2009). Learning Space Mashups: Combining Web 2.0 Tools to Create Collaborative and Reflective Learning Spaces. Future Internet, 1(1), 3-13.

Wheeler, S. \& Wheeler, D. (2009). Using wikis to promote quality learning in teacher training. Learning, Media and Technology, 34(1), 1-10.

Wheeler, S., Yeomans, P., \& Wheeler, D. (2008) The good, the bad and the wiki: Evaluating student generated content as a collaborative learning tool. British Journal of Educational Technology, 39(6), 987-995.

Willingham, D.T. (2008). Critical thinking: Why is it so hard to teach? Arts Education Policy Review, 109(4), 21-32. doi:10.3200/AEPR.109.4.21-32.

Wopereis, I.G.J.H., Sloep, P.B., \& Poortman, S.H. (2010). Weblogs as instruments for reflection on action in teacher education. Interactive Learning Environments, 18(3), 245-261.

Wubbels, T. (2007). Do we know a community of practice when we see one? Technology, Pedagogy and Education, 16(2), 225-233.

Yang, S.-H. (2009). Using blogs to enhance critical reflection and community of practice. Educational Technology \& Society, 12(2), 11-21.

Yenice, N. (2011). Investigating pre-service teachers' critical thinking disposition in terms of different variables. European Journal of Social Sciences, 20(4), 593-603.

Zhou, Q., Yan, C., Zhao, S., Liu, L., \& Xing, L. (2012). A preliminary investigation into critical thinking of in-service and pre-service middle school chemistry teachers in Shaanxi province of China. Asia-Pacific Forum on Science Learning and Teaching, 13(2), 1-13.

Correspondence: Serkan Sendag, Associate Professor, Department of Computer Education and Instructional Technologies, Faculty of Education, Akdeniz University, Antalya, Turkey. 